\title{
De fronteras agrícolas, pioneros y gambusinos de oro verde
}

$\mathrm{H}$ istóricamente, la frontera agrícola de México ha sido rebasada en regiones aisladas, con escasa población y poco comunicadas, en las que impera una agricultura tradicional, por una explotación intensiva agrícola y/o ganadera especializada en el uso de los recursos naturales y humanos para satisfacer la demanda de alimentos o de insumos industriales de un mercado nacional e internacional en crecimiento. En estas regiones se lleva a cabo una gran transformación debido a que se desarrolla una ganadería extensiva que lleva a talar bosques y selvas y a destruir ecosistemas que tenían una existencia milenaria; se implantan monocultivos comerciales que monopolizan los recursos productivos y humanos de la "nueva" área agrícola, a la par que limitan la producción de pequeña escala orientada a satisfacer la demanda doméstica, local y regional de alimentos; se desarrollan agroindustrias que acaparan la producción regional e implantan patrones de cultivo y sistemas de regulación a los agricultores que les abastecen de productos, los cuales pasan a depender de ellas para financiar parte del cultivo y comercializar la cosecha; modifican los sis- temas de contratación y de organización del trabajo y alientan la inmigración temporal y permanente de trabajadores de otros lugares del país para hacer frente a un explosivo crecimiento y diversificación de la actividad económica regional; inciden y modifican en el sistema político local y regional —caracterizado por el poder personalizado de caciques locales y regionales ligados al gobierno estatal y federal- para contar con las condiciones necesarias para su desenvolvimiento.

Estas transformaciones son desencadenadas por cierto tipo de personajes que - por su conocimiento, trayectoria y relaciones comerciales y políticas- perciben oportunidades en estas áreas de frontera donde otros no las ven o no cuentan con los recursos, o bien, no están dispuestos a asumir el riesgo que conlleva aventurarse a producir en regiones “vírgenes". Estos personajes, según advertiremos en sus testimonios, desempeñan un papel central en los albores de estas transformaciones, el cual les es disputado por otros actores económicos que vienen de fuera y que surgen de las localidades y regiones en las que se avecinan. De ahí la prisa por adelantarse y

\section{About Agricultural Frontiers, Pioneers and Green Gold Prospectors \\ HUMBERTO GONZÁLEZ CHÂVEZ: Centro de Investigaciones y Estudios Superiores en Antropología Social-Occidente, Guadalajara, México. \\ hgc@ciesas.edu.mx}

Desacatos, núm. 25, septiembre-diciembre 2007, pp. 193-212. 
mantener el control de la situación durante el mayor tiempo posible.

En este trabajo presento tres narraciones de pioneros que participaron en las transformaciones del paisaje natural y de la producción agropecuaria del sur y de la costa de Jalisco. El primero describe la experiencia de un grupo de pequeños propietarios que, alentados por el gobierno estatal, se asentó en la abundante selva del sur de Jalisco para desarrollar la ganadería y la agricultura comercial. El segundo presenta la visión y las estrategias de un empleado de una empresa estadounidense que llegó al valle de Autlán-El Grullo con el propósito de desarrollar cultivos hortofrutícolas para el mercado de invierno en Estados Unidos. Finalmente, el tercer relato nos muestra a un paradigmático empresario mexicano, descendiente del grupo que "colonizó" la costa, quien, por una parte, evaluó el daño ambiental que causaron en el valle los monocultivos y las malas prácticas agrícolas de productores del valle de Autlán-El Grullo; y por otra, presentó su nuevo proyecto de conquista agrícola, su lectura del paisaje, su visión del mercado y de la política local y nacional.

Los testimonios aquí reunidos son producto de entrevistas grabadas y transcritas unos días después de que se realizaron. Para su presentación procuré ser fiel a la transcripción, pero edité el material para facilitar su lectura y presentación. Esta labor implicó seleccionar los párrafos de las entrevistas que estaban relacionados con el tema de la colonización y organizarlos en incisos para que, desde mi particular punto de vista, facilitaran su comparación y comprensión. Suprimí mis preguntas para presentar un relato de la percepción y de las experiencias de estos personajes, que en la literatura de las ciencias sociales son nombrados como pioneros, innovadores o empresarios (Fábregas, 1994; Schumpeter, 1997; Turner, 1962), y en el habla de los lugareños como fuereños, visionarios, locos e hijos de puta.

Humberto González Chávez

\section{TREINTA AÑOS EN LA COSTA SUR DE JALISCO: DEVASTACIÓN DE LA SELVA, EL BINOMIO DE GANADERÍA Y CEREALES Y, FINALMENTE, LAS PLANTACIONES PARA LOS MERCADOS NACIONAL E INTERNACIONAL}

Narración de Roberto Vargas ${ }^{1}$

\section{El éxodo a la tierra prometida}

Mi padre era originario de Tamazula, Jalisco; al igual que algunas otras familias de medianos y grandes propietarios, tenía dificultades para desarrollarse económicamente debido a la amenaza de ser afectado por los agraristas. Para fines de los años treinta del siglo pasado se había afectado a las haciendas y había demandas pendientes sobre otros propietarios. En estas circunstancias, el general García Barragán — gobernador del estado de Jalisco entre 1942 y 1946 - le propuso a mi padre — que era líder cañero de los pequeños propietarios- $-\mathrm{y}$ a otros propietarios del lugar que se organizaran para comprar un rancho de 10 mil hectáreas que se encontraba seriamente amenazado por un grupo de agraristas de la Costa de Jalisco. Este rancho abarcaba parte del municipio de Casimiro Castillo [llamado así en memoria de un paladín de la reforma agraria y diputado asesinado por los terratenientes en 1925].

El general García Barragán buscaba que un grupo de inmigrantes con experiencia en la agricultura comercial y conocedores de nuevas tecnologías desarrollaran la región. Para que se asentaran y se dedicaran a trabajar les prometió certificados de inafectabilidad del gobierno estatal para que no vieran amenazadas sus propiedades por los agraristas de la región.

Mi padre, junto con otros agricultores de Tamazula, se fue en un camión a visitar la propiedad en venta. Llegaron por un camino de terracería y rentaron caballos para recorrerla. En total fueron doce propietarios jóvenes los que se entusiasmaron y se establecieron con sus familias en el casco de la hacienda llamada Corral de Piedra. Cada

\footnotetext{
${ }^{1}$ Entrevista del 30 de octubre de 1987 en La Croix, Jalisco.
} 


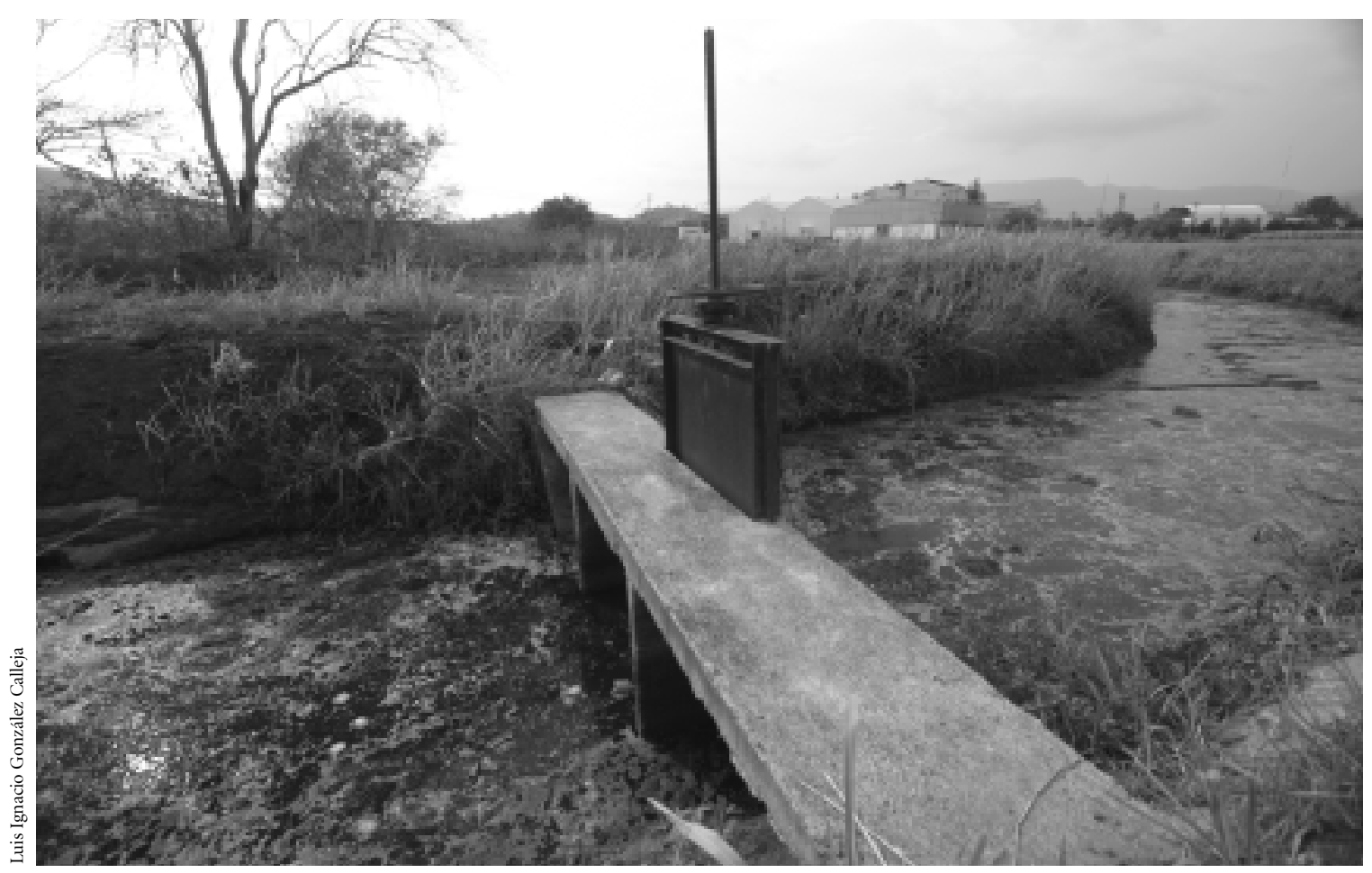

Canal de desagüe del ingenio Melchor Ocampo. El Grullo, Jalisco.

propietario, según sus recursos, compró una porción de la gran propiedad. Mi padre adquirió la "casa grande" de la hacienda y 1800 hectáreas, de las cuales 300 eran de cultivo y el resto tenía monte. Esta propiedad la escrituró entre sus hijos para disminuir el riesgo de ser afectado. Yo tenía cinco años.

En aquel tiempo también se establecieron productores de la región de los Altos de Jalisco. La región de la Costa estaba gobernada por caciques, y mi padre, por su experiencia como líder cañero, se convirtió en la cabeza del grupo de agricultores y habitantes que se establecieron en Corral de Piedra. Había varios caciques en los centros de población de la región, como La Huerta y Cihuatlán. [Todos, sin embargo, desde la década de 1930 reconocían como cabeza al general García Barragán, originario de la vecina población de Cuautitlán, Jalisco. Este cacicazgo se ejerció gracias a las relaciones de este personaje con el gobierno federal y el ejército, que le permitieron ser gobernador del estado.]
Mi padre trajo a una maestra para que diera clases a sus hijos y a los hijos de los demás propietarios y peones que vivían en Corral de Piedra. A esta escuela asistí y unos años después me fui a la primaria de Casimiro Castillo.

Corral de Piedra quedaba incomunicado durante el tiempo de aguas y sólo se podía entrar con bestias. El camino que comunicaba la región con otros lugares del estado se deterioraba durante las aguas y era difícil la comunicación.

Mi padre, junto con propietarios de Tamazula y de otros lugares del estado, comenzó a producir maíz, frijol y calabaza en las tierras agrícolas que estaban desmontadas y a tumbar el monte para sembrar pasto y meter ganado. Las maderas más finas se habían ido vendiendo desde tiempos de las haciendas y se exportaban a otros países. Había algunos aserraderos en la región, pero la mayor parte de los árboles que se tumbaban se quemaban. Había en ese tiempo árboles inmensos que cuatro hacheros no lograban tumbar en todo un día. Los árbo- 
les tumbados durante las secas se dejaban secar hasta el mes de mayo, justo antes de que llegaran las lluvias, y se les prendía fuego. En ese entonces había grandes incendios en la región, que se veían desde lejos. Los horcones de madera que quedaban después de que se apagaba el fuego eran rociados con petróleo y se les prendía fuego para que terminaran de quemarse. Una vez que se desmontaba un predio, se sembraba o se dejaba crecer el pasto para alimentar al ganado. En menos de dos décadas, los cuarenta y cincuenta, se acabó la selva en las partes planas y semiplanas.

Corral de Piedra fue un fermento y una escuela para la agricultura y para la ganadería de la zona. Se introdujeron nuevas razas mejoradas que no se conocían en la región y se trajeron maquinaria y herramientas que antes no se utilizaban. Mi padre trajo el primer tractor. Un día que fue a la ciudad de México compró un caballo en el hipódromo al que se le había quebrado una pata, y se lo trajo para que sirviera de semental. Lo cruzó con las yeguas del rancho y de los ranchos circunvecinos y en las primeras crías pudo ver la diferencia que había con los ca-

ballos chicos y flacos de la región. Igual pasó con las vacas, los puercos, las gallinas, los chivos y los borregos que trajeron de fuera. Las nuevas razas se cotizaban mejor y la ganadería se convirtió en la actividad más rentable.

\section{Los cultivos de plantación para los mercados interno y externo}

En la región se introdujeron nuevos cultivos comerciales para el mercado nacional como el arroz y el tabaco, pero no pegaron. El maíz seguía siendo el principal cultivo, pero mi padre veía que no era una buena opción. Por ello, a principios de los sesenta, mi padre y Sebastián García Barragán, hermano del general [Marcelino], se fueron a la ciudad de México con la idea de conseguir que el gobierno pusiera un ingenio en la región para desarrollar el cultivo de la caña de azúcar. El general los conectó con el secretario de Agricultura y con otros funcionarios que conocía para que les explicaran su proyecto. Fue necesario hacer varios viajes y antesalas con los políticos, hasta que lograron que enviaran funcionarios a la región para ver si era posible que se cultivara la caña, y [que] había una superficie agrícola suficiente para abastecer un ingenio. Los visitantes se hospedaron en mi casa y mi padre los atendió. Mi padre había sembrado un terreno con caña de azúcar para demostrar[les] que ese cultivo se podía cultivar en la región y que los funcionarios visitantes pudieran comprobarlo.

A principios de los sesenta [1962] comenzó a trabajar el ingenio azucarero [José María Morelos]. Los terrenos agrícolas y las mismas praderas ganaderas de los alrededores se sembraron con caña de azúcar. El maíz y el frijol siguieron produciéndose, pero las mejores tierras agrícolas fueron dedicadas a la caña, que era un cultivo más rentable. La región y las gentes cambiaron. Había mucho trabajo y fue necesario que en la zafra de la caña vinieran trabajadores de fuera de la región. Para que trabajara el ingenio fue necesario que vinieran trabajadores de fuera que tenían experiencia, pero también se contrató a trabajadores de la región.

A finales de los sesenta se presentó un nuevo cambio, al llegar representantes de compañías de Estados Unidos que animaron a algunos productores a sembrar sandía y melón. Ellos los asesoraron y les dieron la semilla con el compromiso de que les vendieran toda la producción para enviarla en camión a Estados Unidos. La sandía fue el cultivo que [les] permitió más ganancias a los agricultores, pero también el que tenía más gastos y más riesgo. Durante los setenta, los grandes productores agrícolas de la región, y posteriormente también los pequeños productores y los ejidatarios, apartaron una parte de los terrenos agrícolas que tenían para sembrarlos con sandía. Este cultivo, junto con la caña, dio dinero a los productores para comprar tractores, implementos agrícolas, camionetas y los químicos para combatir las plagas.

\section{Un relevo generacional y un cambio político}

Durante la época en que mi padre viajaba a México su rancho enfrentó fuertes problemas financieros. El dejar de supervisar la producción lo llevó a endeudarse y a tener dificultad para pagar sus deudas. Esta situación con- 
tinuó durante los setenta. Mi padre era muy aventado y muy activo, pero no era buen administrador porque no llevaba contabilidad y, en ocasiones, por no atender los lienzos el ganado se metía a los terrenos y se comía el maíz.

Yo trabajaba en el rancho, pero además asistí a la secundaria y a la preparatoria en Autlán, Jalisco. Ahí conocí a gente de Autlán, y de entre ella a la que años después sería mi esposa. A mí me tocó comenzar con la siembra de sandía en el rancho, porque mi padre no estaba muy convencido y [quise] demostrarle que era buen negocio. Posteriormente, por diferencias con mi padre, me fui de la casa a trabajar en un ingenio de San Luis Potosí. Ahí recibí una carta de mi padre invitándome a que regresara a trabajar en lo propio. Decidí regresar, pero también me inscribí a la Escuela de Veterinaria en la ciudad de Guadalajara, en donde cursé los primeros semestres. En unas vacaciones en las que me di cuenta de la situación del rancho y de lo mermada [que estaba la] salud de mi padre decidí abandonar la Universidad [de Guadalajara] y hacerme cargo del rancho. Las actividades [que hacía] eran las [mismas] que a lo largo de los años había realizado mi padre. Producíamos maíz y frijol, con el que se alimentaban los medieros y trabajadores; criábamos ganado con la pastura del maíz y con las praderas que tenían pasto; producíamos caña de azúcar para el ingenio en los mejores terrenos agrícolas y sembrábamos sandía en los terrenos más planos y de mayor humedad. Mi padre le tenía mucha fe a la caña, pero mi idea fue aumentar la siembra de sandía porque era el cultivo que más dinero dejaba y con el que podía abonar a la hipoteca, comprar maquinaria, fertilizantes y $[\mathrm{cu}-$ brir] los gastos de mi casa y de la casa paterna. Para cuando fui responsable, me casé y mi padre pasaba la mayor parte del tiempo en Guadalajara, en una casa que compró para que mis hermanos estudiaran.

Con la responsabilidad productiva del rancho, pero también con la aprobación de mi padre, vendí los terrenos más alejados, seleccioné el mejor ganado y el resto lo vendí y me concentré en dos cultivos: la caña y la sandía. La caña permitía [tener] un ingreso seguro; en cambio, la sandía tenía variaciones en el precio porque en ese tiempo las compañías fijaban el precio a los productores.
Para finales de los setenta comencé a tener dificultades con mis hermanos, que venían durante las vacaciones al rancho y no les gustaba que les distribuyera actividades que debían realizar y le reprocharon [a mi padre] el manejo financiero que hacía de la propiedad familiar. Como no encontré respaldo en mi padre ante los reproches de mis hermanos, en 1979 decidí dejar el rancho e irme a vivir a Autlán. Me quedé con un tractor y con 33 hectáreas de las 150 de cultivo que quedaban del rancho. Estas últimas, sin embargo, tuve que pagarlas porque mis hermanos se opusieron y por esta razón me hice responsable de un crédito que tenía el rancho con la banca oficial. En Autlán compré un terreno de nueve hectáreas de riego y con capital de mi suegro y con la guía de un concuño comencé a sembrar jitomate para el mercado nacional y de exportación.

Mis hermanos se hicieron cargo del rancho y en poco tiempo advirtieron que no daba el dinero [que] habían pensado. Además, tuvieron que hacer frente económicamente a las amenazas de afectación de grupos de solicitantes que presionaban a la Secretaría de la Reforma Agraria para que repartiera las grandes propiedades de la región. El certificado de inafectabilidad que había recibido mi padre cuando compró el rancho no tenía valor porque [le] había sido otorgado por una autoridad estatal en un ámbito que era competencia del gobierno federal y, en todo caso, [le] había sido dado para una propiedad ganadera que se había vuelto agrícola. Para ese tiempo, el general García Barragán había venido a menos políticamente desde los años setenta, cuando entró el presidente de México Luis Echeverría [1970-1976]; por otra parte, también [había] perdido su fuerza con los funcionarios estatales y con los gobiernos locales.

Mis hermanos querían defender el rancho con [las] armas, pero yo les hice ver que no tenía sentido y que de cualquier manera el rancho, al igual que otras propiedades de la región, iba a ser afectado.

Al poco tiempo de estar en Autlán, Corral de Piedra fue la primera propiedad en ser afectada y repartida entre los solicitantes sin tierras. 


\section{EL VALLE DE AUTLÁNY EL GRULLO: UN OASIS PARA COMPAÑÍAS TRANSNACIONALES}

\author{
Narración de Eduardo Castillo²
}

Yo soy un pionero...

[En 1947 el gobierno federal fundó la Comisión del Tepalcatepec para desarrollar la cuenca hidrológica del río Balsas. Su primer y único director fue el general Lázaro Cárdenas, quien fuera presidente de México en el periodo de 1934 a 1940. El General tenía el proyecto de desarrollar en lo agrícola y lo económico una región de su natal estado de Michoacán, que estaba aislada y había sido considerada inhóspita y poco productiva. Su propósito era establecer en poco tiempo una agricultura moderna en la región del Tepalcatepec con la construcción de un sistema que aprovechara el agua de los afluentes del Balsas (Cupatitzio y Cajones) y a partir de una reforma a la propiedad de la tierra mediante la afectación de las grandes propiedades ganaderas de la región y el reparto de parcelas de riego a trabajaestado y del país, que se establecieron en la región y formaron nuevos núcleos de población (Pérez-Prado, 2002).]

Yo fui pionero en Apatzingán y me tocó abrir las tierras al cultivo para sembrar algodón, y después para sembrar melones y otros cultivos que el valle aceptó. Yo trabajaba en la región de La Laguna y fue gente del General la que nos invitó a varios productores de algodón a venirnos a Apatzingán una vez que entró en operación el sistema de riego. Los productores que recibieron la tierra sólo sabían sembrar los cultivos tradicionales y criar ganado. Nosotros sembrábamos algodón y cultivos de exportación en la región de La Laguna [situada en los límites entre los estados de Durango y Coahuila]. En Apatzingán conocí y entré a trabajar con una compañía de McAllen, Texas, llamada Griffin \& Brand, la cual era propiedad del señor Otto Brand. Después de estar un tiem-

\footnotetext{
2 Entrevista grabada el 11 de marzo de 1988 en el restaurante El Toro Viejo, Autlán, Jalisco.
}

po en Apatzingán, el señor Brand me envió a Tampico, donde se echó a funcionar un sistema de riego y pasamos a sembrar algodón y melón. Nuevamente me tocó participar en el desmonte y en la incorporación de grandes propiedades ganaderas a la agricultura moderna.

Hacia 1967, el señor Brand me encargó buscar una región en la que pudiéramos cosechar melón durante los meses de abril y mayo, porque en ese tiempo hace mucho calor en Apatzingán y no es un clima bueno para cultivar este fruto. La mejor temporada para producir melón en este lugar es de mediados de noviembre a marzo.

\section{De pionero a gambusino del oro verde}

Casualmente conocí al señor Black Dois, que al igual que yo trabajaba para una compañía de Texas. Le comenté que andaba buscando una región nueva para producir durante el invierno. Él me habló de un lugar de Jalisco llamado El Grullo, que tenía mucha agua. [En 1958 se terminó de construir la presa de Tacotán, que retiene el agua de los ría Armería y Ayuquila. Durante toda la década de 1960 se construyeron los canales principales y secundarios que permitieron irrigar parte del valle donde se encuentran los municipios de Autlán, El Grullo y El Limón (Román y Silva, 2006).]

El señor Dois me invitó a visitarle y el lunes 2 de enero de 1968 llegué al hotel Autlán y me fui a visitarlo a El Grullo. Me llevó a ver un campo pequeño en el que tenía sembradas semillas de diversas variedades de melón para observar cuáles eran las que mejor se adaptaban a las condiciones del área y poderlas solicitar a su compañía para producir melón en el valle. Me enseñó el valle de Autlán, ya que su dedicación era El Grullo. A simple vista me encontré con una desolación gigante. No había movimiento en las calles y había muy poco comercio, nomás el de la plaza de armas y una que otra tiendita. Pregunté a alguna gente con la que me encontré por qué estaba tan desolado el pueblo y me contestó que anteriormente la gente vivía muy bien cuando estaba la Minera Autlán. ${ }^{3}$ [Pero]

\footnotetext{
${ }^{3}$ Esta fue una empresa estadounidense que se estableció en 1953 para
} 


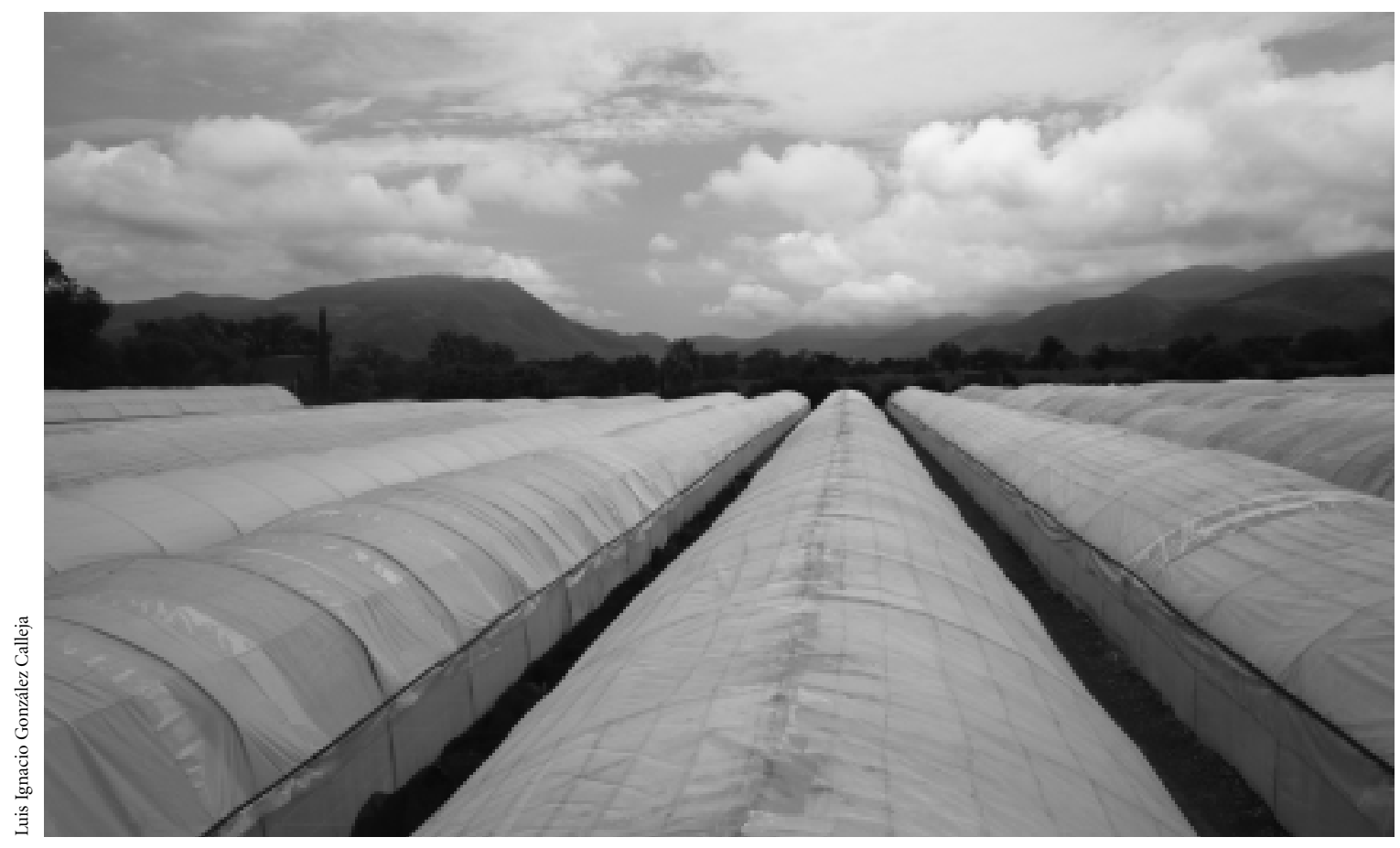

Zurcos de invernadero, Autlán, Jalisco.

al irse la minera, muchos emigraron a Guadalajara o a otros lugares de México y sólo se quedaron los que tenían ganado y los que sembraban maíz de temporal. Por esos años, los productores del valle no le entraban muy duro al sorgo. La productividad del maíz era baja porque las mazorcas eran unos molonquitos chiquitos

En Autlán me hablaron de un tal señor Adán Uribe, que tenía información que entregaba a solicitud de la Secretaría de Agricultura y Ganadería, con oficinas en El Grullo. Lo fui a ver y me facilitó el reporte meteorológico de Autlán de los últimos treinta años, donde estaban registradas las variaciones de temperaturas y de precipi-

explotar una veta de manganeso que se agotó a finales de la década de 1960. Para esos años tenía explotaciones más rentables en el estado de Hidalgo y concentró sus operaciones en este lugar. Los lugareños dicen que esta empresa se llevó de Autlán hasta el nombre, porque siguió llamándose "Minera Autlán". Durante el tiempo que operó en la región diversificó y dinamizó la economía y, después de la agricultura, fue la principal fuente de empleo. Al irse se presentó un decaimiento económico notorio principalmente en la ciudad. tación pluvial. Al revisar esta información me di cuenta de que había encontrado el lugar exacto, un valle [en el] que podía sembrar de todo, todo el año. Prácticamente no había invierno, porque todo el año era primavera. Te imaginas: ¡todo el año primavera! Muy fresco en la noche, ideal y mejor clima en las noches que Guadalajara, donde calienta. Un clima en realidad increíble.

Pero no había agua, porque el sistema de riego que se había construido con la presa de Tacotán llegaba aproximadamente a la mitad del valle y beneficiaba principalmente a los de El Grullo. En Autlán sólo había tres pozos. Uno lo tenía Seberiano Michel, otro muy destartalado era de Honorato Villaseñor, dueño del rancho el Pabellón; finalmente, había un pozo todo chueco que tenía Luis Felipe Castañeda en un lugar que llamaban el Mojo y [del] que [se] sacaba algo de agua.

Ya que comencé a ver el lugar me gustó, me gustó, me gustó el valle. Con los datos que había consultado y con las pláticas con la gente que sembraba algo tuve la seguridad de que había dado con el lugar exacto. El señor 
Uribe me recomendó que fuera con don Jaime Llamas, el cual me introdujo con otros agricultores y me dio información que me fue muy útil. Me presentó a Seberiano Michel, al que le renté un terreno que estaba sobre la carretera, a la entrada del pueblo, y a Luis Felipe Castañeda, que tenía una granja porcina y con quien hice buena amistad. Después me conecté con el señor Ramón Corona, dueño de un terreno grande llamado el Terronal. A este rancho también le llamaban el Paraguas, porque nunca llovía. Dicho sea de paso, este rancho fue lo que a mí más me gustó de la zona. Una propiedad de 100 hectáreas en donde no llovía daba la oportunidad de [que] uno fuera quien dominara la situación del campo. Este terreno estaba lleno de breña, al igual que los terrenos de Seberiano, donde el pozo le daba muy poca agua.

Yo no podía creer que hubiera dado con un lugar así, con un valle lleno de montañas donde no llovía. Es uno de los lugares [en] que menos llueve de la costa de Jalisco. [En] El Grullo, situado a unos cuantos kilómetros de Autlán, llueve mucho. Las corrientes de aire que entran al valle hacen que caminen las nubes de agua que vienen

de Colima o de Tapalpa y no dejan que se desagüen sobre Autlán. El caso de El Grullo es diferente porque llegan nubes de Unión de Tula y de Ahuacapán y al encontrarse se desaguan. Autlán es seco. ¡Casi no podía creerlo!

Mis nuevas amistades me fueron de gran utilidad para conocer el valle y definir quién es quién en el lugar. Los bancos del lugar también me orientaban sobre la gente.

[ A la pregunta de por qué no consideró las tierras del sistema de riego, me contestó:] En aquel tiempo no había revestimiento de los canales y todas las tierras que analicé dentro del valle eran salitrosas. Esto se debía a la filtración del agua de los canales de agua del sistema de riego. La humedad se llegó a uniformar en toda el área irrigada porque el manto freático estaba muy cerca y a un metro y medio se podía sacar agua. La parte irrigada del valle de Autlán-El Grullo-El Limón se había transformado en algo así como un pantano con muchas sales. Las cosas ahora han cambiado por la caña y porque los canales están revestidos con una plancha de cemento. Los riegos constantes de las tierras han lavado el salitre; sin embargo, a pesar de estos cambios el área de riego no era el sistema ideal para sembrar hortalizas.
Nosotros [los productores hortofrutícolas] buscamos las tierras bermejas, que no existen en el sistema de riego con excepción de algunas laderas; el resto eran tierras planas, con canales de agua y de desagüe, pero sin revestir. Las tierras del sistema de riego, por otra parte, son arcillosas. Las de los alrededores de Autlán son semiarenosas y drenan el agua de la lluvia de forma increíble, a tal punto que cuando llueve puedes entrar inmediatamente a fumigar y no te manchas los zapatos. Era un conjunto de cualidades... que de los valles que yo conozco en toda la República mexicana no encuentro otro valle que reúna todas estas cualidades para el desarrollo de las hortalizas. Mira que conozco a las gentes que siembran hortalizas en toda la República, con excepción de Campeche, Quintana Roo y Yucatán.

El otro factor que el valle tiene a su favor es la altitud de mil metros sobre el nivel del mar. Esta característica es muy importante, porque pasando de esta altitud hiela durante el invierno en cualquier parte de México. De acuerdo con los registros del señor Uribe, en treinta años nunca había bajado la temperatura a cero. Autlán era un valle primoroso, casi siempre con un mismo microclima. ¡Primavera todo el año!

Me informé también con el ingeniero Sevilla, de la oficina de la Secretaría de Recursos Hidráulicos, quien me habló y me dejó consultar un estudio muy completo sobre el agua del subsuelo que la Secretaría había realizado para construir la presa de Tacotán y los canales de riego. Este estudio me aseguraba un abastecimiento de agua del subsuelo por buen tiempo. Un geólogo de la Secretaría me aseguró que no tendría ningún problema de agua.

También me informaron que en Ayutita [una comunidad campesina situada en un lugar un poco más alto, pero en el municipio de Autlán] sembraban hortalizas que vendían en los mercados de la región. Estos labradores contaban con un arroyo de agua que nacía en la sierra. Me fui a platicar con ellos para conocer los cultivos que tenían y, sobre todo, las épocas de siembra. Quiero aclarar que esta información era clave para mí porque yo llevaba un calendario de fechas de la compañía que me marcaba abril y mayo para levantar el melón ${ }^{4}$. Basado en la

${ }^{4}$ La Griffin \& Brand era una empresa que ofrecía a sus clientes abas- 
guía del servicio meteorológico, sabía que no podía fallar si iniciaba la siembra de melón en enero. En Autlán hace un poco más [de] frío que [en] El Grullo, donde sembraban [a] fines de diciembre. Tenía que levantar la cosecha del 10 de abril hasta el 20 de mayo 5 .

Para producir hortalizas es preciso tener las fechas exactas de siembra. Se debe buscar el momento en el que no hay producto en el mercado y se puede obtener el mejor precio. Es importante [alzó la voz y golpeó la mesa] comenzar a producir en una fecha exacta para quitarte la competencia.

\section{Madrugar para quedarme con lo mejor}

Después de varios días de estar en el valle tenía una serie de datos que para mí eran casi la Biblia y comencé a rentar tierras. Renté el rancho de Seberiano de 70 hectáreas y el Terronal de 100 hectáreas. También renté 70 hectáreas a Sebastián Michel. No tenía competencia. Nadie estaba sembrando ni trabajando. Los que producían eran los que tenían ganado. Donde había agua rodada era otra cosa, porque estaba Lagunillas, El Mentidero, La Aldaba, Vaquerías, Rincón de Luisa, donde tenían maíz, alfalfa y otros cultivos.

Yo tenía el apoyo económico de la compañía y trataba directamente con el señor Brand. Más adelante, cuando ya habíamos comenzado a producir, el mismo señor Brand vino en su avión a conocer el valle. A mí me consideraba de plena confianza y era un almacén de entrada de dólares y salida de frutas. Al terminar cada ciclo, hacía cuentas y me hacían la liquidación.

Para comenzar a producir traje una máquina perforadora portátil y perforé en donde está ahora el seminario. Hice un pozo y saqué agua con un tubo de ocho pulga-

to de melón con la misma calidad durante todo el año. Para cumplir esta oferta debía escalonar la producción en diferentes lugares de México y de Estados Unidos y así tener producto en sus bodegas de Mc Allen, Texas, durante todo el año (González y Calleja, 1998).

${ }^{5}$ El 16 de mayo era la fecha límite para enviar melón de México a Estados Unidos porque entraba en vigor un arancel a las exportaciones de México, ya que para esa fecha se iniciaba la cosecha de melón en el sur de Texas. das que me permitió irrigar las 70 hectáreas. En el terreno de Seberiano arreglé el pozo y tuve 70-80 litros por segundo. En el predio del Terronal perforé dos pozos para regar todo el campo.

El trato que hice con los propietarios fue pagar una renta por adelantado por cinco años y al concluir este tiempo la perforación y el equipo de bombeo se quedaban con el propietario. Ese año pagué por el Terronal una renta anual de 1330 pesos por hectárea. Su propietario recibía una renta por año de mil pesos por yunta [cuatro hectáreas aproximadamente]. Pagar una renta alta para los de Autlán tenía como finalidad que el dueño no me fuera a decir que no, ya que se trataba de una propiedad muy cómoda, al borde de la carretera y en un lugar que estaba seguro de tener agua.

Para hacer los pozos, yo traía una tecnología avanzada y conocía muy bien el sistema de perforación y de bombeo, porque había tenido que perforar muchos pozos en La Laguna. Había allí una tradición de perforación de pozos profundos, ya que había más de mil. Supervisé el trabajo de perforación para que se hicieran pozos bien hechos, que siguen jalando hasta ahora.

El señor Ramón Corona, dueño del Terronal, que vivía en Guadalajara con su esposa, tenía contratos con medieros, con diferentes fechas de vencimiento cada uno. Como me dijo que no podía echar a sus medieros, le pedí autorización para hablar con cada uno de ellos y [de] convencerlos de que dieran por terminado su contrato. A todos los vi y a todos los liquidé pagándoles lo que sacaban de maíz y la pastura para alimentar su ganado. A unos les compré hasta lo que tenían, como mulas, aperos y un tractor Ferguson nuevecito; todo lo que tenían allí se los compré para poderme quedar con todo el rancho. Los liquidé a como quisieron. Unos tenían contratos por dos y tres años y se trataba de un montón de parceleros, unos de menos potencialidad que otros. Me recuerdo que uno me decía: "Yo tengo mulas y, si dejo de sembrar, ¿qué voy a hacer con las mulas?"; a lo que le contestaba: "Véndeme las mulas". Se las compré con todo y aperos. Otro me dijo: "Yo tengo un remolque", y otro: "Yo tengo un tractor". Y todo lo compré, hasta que me quedé con todo el rancho. No hubo problema de quien se resistiera, porque lo que me pidieron les di: "Dígame, 


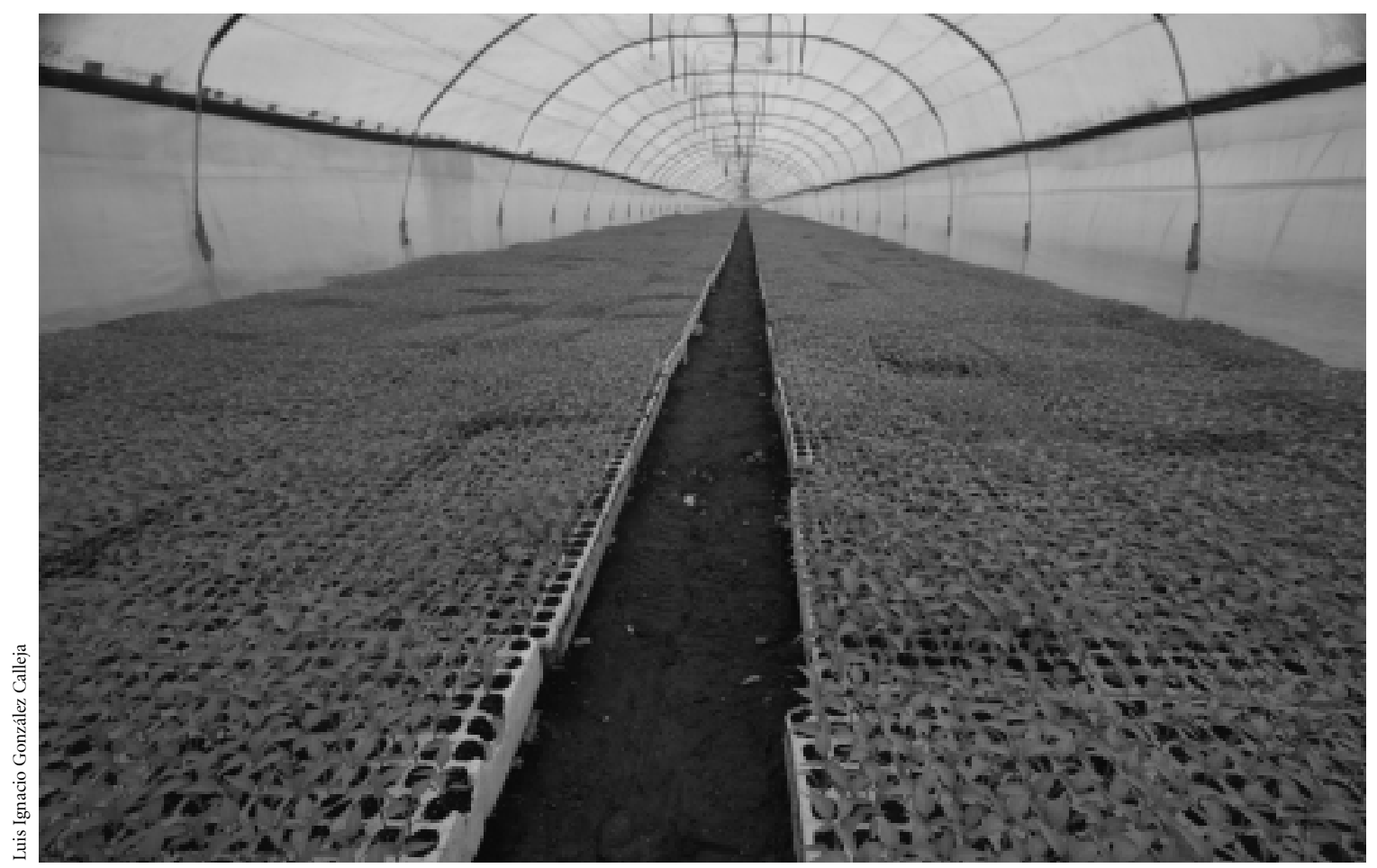

Germinación y producción de plantas en invernadero. Autlán, Jalisco.

señor, cuánto quiere...” A lo que les respondía que fueran ellos los que fijaran el precio y así, alegando, ellos acababan por decir una cantidad que yo, inmediatamente y sin regateo, aceptaba pagarles. Por otra parte, yo ya tenía un contrato firmado por los dueños del rancho y esta información se las decía desde el momento que hablaba con ellos.

Había gente sobrada para trabajar, principalmente mujeres, porque el hombre en esta región no jala tan bien. Antes se hablaba de mozos y de yuntas, o sea, que estaba la cosa un poquito arcaica. Yo pagaba el sueldo que se debía pagar, que era el salario mínimo, y además pagaba el séptimo día; invariablemente cada sábado pagaba. Introduje el sistema de tarjetas. Por fuera se me criticaba un poquito, porque decían que "ese señor de fuera que viene a cambiar los sistemas". Decían: "Ese cabrón viene pagando un chingo, ha de traer mucho dinero".

[A la pregunta de que si no hubo problemas para dejar trabajar a las mujeres en el campo, me dijo:] No los hubo por cuestión del dinero, porque la mujer para el dinero es cosa seria. Se abocaron al campo, no obstante que no había costumbre de que así fuera.

En las tierras que renté sembré melón con un éxito bastante grande. En los años posteriores nos lanzamos a sembrar otros cultivos, como pepino pickle, calabacita, cebolla, chile morrón y fresa. Esta última se dio bien, pero faltaba un poco de frío para que dejara de crecer y diera fruto, y en Autlán no había temporada fría. Por otra parte, para este último cultivo es necesario construir una procesadora y era una inversión muy alta que al señor Brand no le interesaba hacer en Autlán, porque producía y procesaba fresa en Zamora, Michoacán. Sin embargo, la fresa que se dio en el valle era muy dulce y de buena calidad, que bien podía haberse producido para el mercado de Estados Unidos, que es nuestra finalidad.

Después comenzamos a producir tomate. Fue valiosa la información que obtuve de los productores de Ayutita para identificar las fechas de siembra. Comenzamos en 
junio a sembrar las semillas para producir planta y cosechamos en octubre, noviembre y parte de diciembre. En esos meses estábamos libres de toda la competencia de la República mexicana, es decir, de todo aquel productor que sembraba tomate en vara, porque nadie tenía un valle como el de Autlán. Podíamos exportar, pero también vender en el mercado nacional.

La compañía del señor Brand era entonces de las más fuertes en México y estaba en primer plano en fresa, cebolla, melón, pepino, calabacita, tomate cherry. Tenía empaques en Zamora y en Apatzingán, Michoacán; y en Irapuato, Guanajuato. Cultivaba cebolla en Tampico, Coahuila y Morelos. Producía en el sur de Veracruz, Colima, Zacatecas, Oaxaca, Chiapas. También se había extendido a Guatemala, Honduras y El Salvador. En Estados Unidos sembraba en Texas, Nuevo México, Florida y California. El señor Brand hablaba español, al igual que su personal. [En una entrevista al señor Otto Brand comprobé que su español era muy limitado, como limitado era el inglés del señor Castillo. Por esta razón fue importante para esta empresa contar con personal mexico-americano del sur del estado de Texas, que aprendió el español en casa y el inglés en la escuela.]

En unos pocos años este valle ha llegado a tener los más altos avances de cualquier otro en Europa o en Estados Unidos. El valle de Autlán floreció de la noche a la mañana, como florecen las cosas en México. Apatzingán, en dos años; Tampico, en dos años; Bolsón de Mapimí, que está en Torreón, en un año o dos. Nada que en veinte años. Autlán hoy día tiene riego por goteo, fertilizantes líquidos ácidos, se controla la cuestión hormonal de plantas, se tiene al día la oferta de variedades de semillas y se siembran de 30-40 variedades nuevas. Este valle después de casi treinta años no se ha parado de tecnificar, integrando la tecnología más avanzada agrícolamente. Hay gente que desconoce cómo funciona el valle de Autlán porque es pequeño, pero internacionalmente, en Estados Unidos, adonde llega la fruta del valle, nos tienen bien identificados y nos conocen por la fruta que llega en una época en la que sólo tenemos la competencia de Florida en Estados Unidos. Noviembre y diciembre son los mejores meses en cuanto precio, y son los meses que tiene Autlán.

\section{LA PESTE EN EL VALLE DE AUTLÁN Y UNA NUEVA TIERRA DE OPORTUNIDAD: EL LLANO DE JUAN RULFO}

\author{
Roberto Vargas 6
}

\section{El espejismo de la abundancia}

Los pozos de Autlán se hicieron con la finalidad de cultivar productos comerciales, ya que la agricultura tradicional tiene la limitante de que no puede costear los equipos de riego, ni la inversión inicial en la perforación y electrificación, ni el mantenimiento. Es una agricultura de subsistencia, nada más. Sólo los cultivos hortícolas $\mathrm{y}$ frutales pueden amortizar los gastos de pozos profundos. En Autlán se hicieron pozos de donde salió mucha agua; pero hubo un gran desperdicio de ella. Todo mundo tiraba y tiraba agua. Por otra parte, el sistema de riego rodado es un crimen, un crimen internacional porque estás lixiviando los fertilizantes y tiras una enorme cantidad de agua a la salida de los surcos. Todo surco tira una porción grande de agua, de lo contrario no queda regado el final. Se tiene que tirar agua, particularmente en terrenos de muy mala nivelación, como son la mayor parte de los terrenos del valle y de México.

Los pozos que se perforaron se estuvieron utilizando a toda su capacidad, día y noche, para sembrar tomates, chiles, calabazas y otros cultivos. Se hizo de Autlán un emporio; un emporio pequeñito, porque la superficie del valle es pequeñita. Pero entonces se comenzaron a agotar los mantos. Los primeros acuíferos que se agotaron fueron los de la zona más alta, donde tengo mi rancho. Al disminuir el agua que podía sacarse, las compañías desecharon la tierra alta y se cambiaron a la parte más baja del valle. Ya no se podían sacar 100 litros por segundo, sino cinco o seis, y no eran nada para regar una superficie de 40 o de 50 hectáreas. Entonces me puse a perforar un pozo a 150 metros y volví a encontrar agua, pero de menos cantidad, como 25 litros por segundo. Esto suce-

\footnotetext{
${ }^{6}$ Entrevista realizada durante el recorrido por los municipios de To-
} nalla, Jalisco, el 12 de noviembre de 1987. 
dió en 1981. También se dio el caso de compañías que hicieron pozos a una profundidad mayor y que afectaron a los dueños de pozos cercanos, los cuales se secaron o disminuyeron su rendimiento a tal punto que fue incosteable seguirlos operando. Esta situación provocó conflictos. Se dio el caso de una compañía norteamericana ${ }^{7}$ que hizo una perforación y afectó las fuentes de suministro del agua potable de una población, porque se habían hecho pozos para surtir de agua a Autlán. [Este hecho implicó problemas serios para el gobierno local, debido a la escasez de agua, precisamente en la población, particularmente durante el tiempo de mayor calor (febrero a mayo).]

Las autoridades contestaron: "Ahorita ponemos remedio", porque la ley dice que el agua primero debe ser utilizada para la población, después para los animales y por último para la agricultura. Pero se encuentran que la compañía causante de la escasez es extranjera y no hay nada que hacer. La solución fue que el pueblo se quedara sin agua. [La situación que nos describe el señor Vargas se presentó no sólo por un pozo, sino por el conjunto de perforaciones que en los diez años anteriores se habían hecho y habían abatido el manto freático del valle (González, 1994). Por otra parte, la posición de la compañía extranjera y de otras fue que si se afectaba su plan de producción se iban del valle y con ello se crearía una escasez de empleo local en la agricultura. La población y sus autoridades sabian lo que sucedía cuando se marchaba la principal fuente de empleo local, debido a que una situación de esta naturaleza se presentó cuando se marchó la compañia Minera Autlán. Finalmente, esta situación deja ver la debilidad de los gobiernos locales ante los inversionistas extranjeros y ante la determinación de las autoridades federales de dar prioridad a la producción sobre las necesidades de agua de la población.]

La zona donde tengo el rancho en Autlán es muy arenosa y requiere de mucha agua. Pero tenía un pozo que daba 100 litros por segundo y me permitía sembrar has-

\footnotetext{
${ }^{7}$ El señor Vargas no quiso darme el nombre, pero pudo haber sido G\&B, Dixon o Vergeles, que era una sociedad del estadounidense Bill Cobayachi y del mexicano Francisco Simón. Esta compañía estaba registrada en México y en Estados Unidos, donde tenía instalaciones y personal de venta.
}

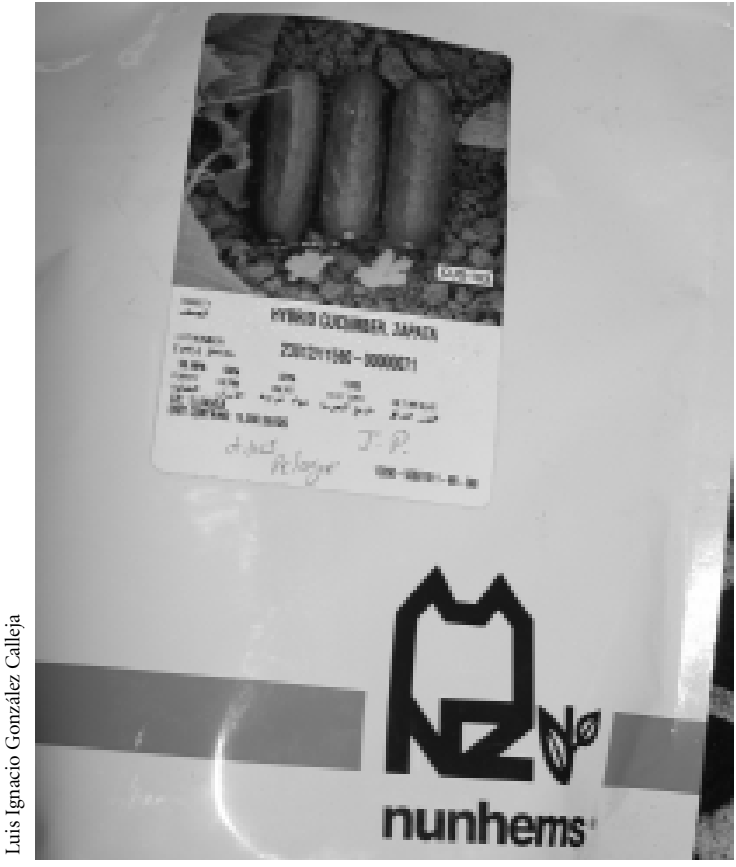

Semillas híbridas de pepino (usufructo privado de un bien público).

ta 50 hectáreas. Tenía una buena producción con variedades de polinización abierta que trajeron las compañías norteamericanas y resultaron buenas para la región.

En 1982 metí el primer sistema de riego por goteo en Autlán, para contrarrestar la escasez de agua. Este sistema lo traje de Estados Unidos, porque no se producía en México. Este sistema lo vi en un rancho de un amigo mío llamado Steve Bandol en California, quien tenía un rancho llamado Three Brothers, una de las mejores explotaciones del estado, y me vendió a crédito todo el equipo. Pude con el agua que me quedaba volver a sembrar las 40 hectáreas que acostumbraba. Además, traje una variedad de semilla híbrida que en lugar de 25 dólares la libra me costó 750 dólares $^{8}$ y logré una producción de 4250 cajas por hectárea, cuando la producción promedio en el valle andaba entre 1500 y 1800 cajas. En la primera cosecha pagué mi deuda con el señor Bandol.

\footnotetext{
${ }^{8}$ En ese tiempo las variedades que había en Autlán eran de polinización abierta; por otra parte, no había experimentación de nuevas variedades de semilla para valorar su adaptabilidad al valle.
} 
El riego por goteo fue muy criticado. Los grandes productores dijeron que era un disparate, demasiado caro, que no servía para la hortaliza y que iba a ser un fracaso. En terrenos arenosos y secos se necesitan hasta dos litros por segundo por hectárea con el sistema de agua rodada; de tal manera que un pozo de 100 litros por segundo podía dar agua para 50 hectáreas. Con el sistema de riego por goteo, con un pozo de 25 litros por segundo y un buen conocimiento y manejo de este sistema pude regar 75 y 80 hectáreas. Este resultado fue sencillamente ¡fantástico!, ¡una maravilla! Se ahorró muchísima agua y se invirtió mucho dinero en el equipo; demasiado dinero. Se cometieron errores al comprar un equipo demasiado caro. Hoy se prefiere comprar el equipo mexicano, que resulta eficiente y mucho más barato. Estas cosas las hemos venido conociendo después. Al darse cuenta de los resultados, los otros comenzaron a comprar también riegos por goteo y adquirir mejores variedades de semillas.

\section{La cruda realidad de la "nueva agricultura"}

Hay un refrán que dice: "Con tierra, agua y tractor, cualquier pendejo es agricultor”. Pero yo cambiaría el final y agregaría [que] es mal agricultor. La agricultura moderna requiere de una gran capacidad porque son exageradamente caros el suelo, los insumos, la maquinaria, la energía, la mano de obra. Todo se ha vuelto muy complicado. Ahora bien, en México la agricultura ejidal no tiene futuro porque, no obstante que hay entre ellos [los ejidatarios] personas muy buenas y muchos son muy trabajadores, no saben ni la o por lo redondo. ¿Cómo van a producir? Si uno le dice al otro: "Yo le puse de un negrito y me dio más, y tú, compadre, ¿de cuál le pusiste?" El compadre le responde: “... del blanquito”. Al hablar del negrito, normalmente se está refiriendo al superfosfato, que es básicamente fósforo. Entonces, esta persona le puso fósforo sin saber si su tierra lo necesitaba; el otro le puso del rojito, que normalmente es potasio, sin saber si sus plantas y su suelo lo necesitaban; el otro le puso nitrógeno, sin saber si lo necesitaba. Ahora bien, el que le atinó y tuvo mejor cosecha que el resto fue por tino, por suerte.

Qué cantidad tan enorme de fertilizante se tira sin ne- cesidad. Qué cantidad tan grande de errores se cometen por no saber la forma de fertilizar; miles de millones de pesos se desperdician porque no se aplica el fertilizante como debería ser. Entonces, ¿cómo es posible que una persona con esta cultura entienda qué es una bacteria y cómo la debe combatir? Todo lo que no conoce dice que es chahuistle y no distingue si es una bacteria, un virus o es la secreción de un pulgón. Pero ahora se han desarrollado las enfermedades a niveles increíbles; hay que entender una cosa: las semillas modernas, así como han aumentado su productividad exageradamente, casi todas ellas, de una u otra forma, tienen menos resistencia a muchas enfermedades. Veamos, un caballo de sabana de este lugar no va a correr a 60 kilómetros por hora porque está acostumbrado a tomar agua sucia, a comer hasta palos y a vivir en estas condiciones. Un caballo de pura sangre, pues, si no se le da buen alimento, pronto va a dejar de ser caballo, pues se va a morir. Lo mismo les pasa a las plantas de semillas finas; necesitan un mayor cuidado: podas, fertilización, fumigación.

El problema grave en Autlán fue el criterio del comerciante: "Yo necesito tomate de Autlán porque tengo infraestructura, y yo quiero que siga habiendo tomates la mayor parte del año." Ese fue el grave problema de Autlán. Porque el valle no se iba a quedar sin plantas de tomate y de otras hortalizas ni siquiera los meses secos de abril, mayo y junio. Los patógenos — sean virus, bacterias u hongos - son muy [s] electivos, son bastante selectivos y atacan a la misma planta. Para que me entiendas, que si ahorita estamos sembrando tomate y en seguida sembramos tomate y luego tomate, se va a hacer muy selectivo el patógeno y va a querer comer tomate. Si cambias de cultivo, por ejemplo, una cucurbitácea [como la calabaza, el melón o el pepino] u otro tipo de plantas, inclusive una gramínea [como el maíz], se reducen los niveles de patógenos. Los insecticidas y fungicidas funcionan hasta una determinada cantidad de esporas o insectos por milímetro cuadrado, y en la medida en que este límite es rebasado, ya no funcionan y no es posible controlar las enfermedades en el campo, y los efectos se vuelven "trigonométricos". Yo estoy cosechando en noviembre, diciembre y enero y tengo un $10 \%$ de plantas virosas. Si en seguida hago un cultivo de la misma planta, cuando to- 
davía no termino de cosechar; entonces mi 10\% de plantas con virus se me va a volver 25 . Ahora bien, si no he terminado con esta segunda etapa de un mismo cultivo y comienzo otra, entonces el porcentaje de plantas virosas se me vuelve el 30-40\% en la tercera etapa y [así] hasta llegar a $100 \%$, [el] total. Ahora bien, si siembro un cultivo diferente y logro cortar la enfermedad, mi porcentaje de plantas virosas se me reduce a un 10-15\% y se corta porque hay un cultivo diferente. De esta manera podemos durar muchos más años así. La plaga necesita un punto de apoyo para extenderse y, si se lo quitamos, evitamos que siga creciendo.

En 1982, cuando se veían los problemas de los patógenos, Bill Cobayachy [propietario de la empresa Vergeles] trajo al doctor Paulus de la Universidad de California, y posteriormente al doctor Hains. Ellos dieron la voz de alarma y corroboraron que, efectivamente, lo que pensábamos nosotros era cierto: se iba a acabar el valle si se seguía abusando de él. Las palabras que ellos dijeron fueron éstas: "Así como es de bueno el valle, porque tiene un clima tan estable y es tan rica la zona; así de bueno como es para las plantas, así de bueno es para los patógenos y los insectos; porque como no tienen temperaturas extremas de frío ni de calor nunca y se puede cultivar cualquier cosa y cualquier día, también a cualquier hora se puede reproducir cualquier insecto." No existe una limitación natural de insectos, como sucede en otras zonas donde existen fríos y calores extremos o donde hay climas demasiado secos o demasiado lluviosos.

En Autlán hubo algunos que nos molestamos cuando Arturo Jiménez, con sus socios Arturo León y el ingeniero Valdez, metieron la siembra de tomate de primaveraverano; ellos fomentaron el desorden. También los secundaron unos pocos ejidatarios y pequeños propietarios.

[El problema de sanidad en Autlán, como señalan el senor Vargas y los fitopatólogos a los que hace referencia, obedecía a la alta concentración de un mismo cultivo en un valle en el que las plagas se reprodujeron en forma incontrolada y crearon resistencia a los insecticidas. Una situación similar se presentó años antes en Autlán y El Grullo con el cultivo de melón, que fue abandonado debido al problema de la sanidad (González, 1993), y también en otras regiones con monocultivos hortofrutícolas en gran escala pa- ra los mercados nacional y de exportación (Garzón, 2002; González, 1993, 2004; Macías, 2006). La segunda etapa, sin duda, agravó y aceleró este problema, pero el origen estaba en el desarrollo a gran escala de monocultivos que especializaron la producción del área.]

Varios nos opusimos y no quisimos meter la segunda etapa porque sabíamos que el valle no iba a aguantar; por otra parte, no tenía caso, si estábamos haciendo muy buen negocio. ¿Qué necesidad había de seguirle?

El daño fue tan grave que no sólo afectó el suelo. Las compañías norteamericanas dañan y abusan de los recursos acuíferos y de la fertilidad del suelo. Pero el daño en Autlán rebasó toda expectativa. Fue un daño ecológico. El daño se extendió a la fauna y la flora. La enfermedad se salió de los campos de cultivo y se nos fue a una gran variedad de plantas silvestres. Hoy tenemos una gran variedad de plantas silvestres enfermas del virus que crecen con las lluvias y dañan las plantaciones de tomate. A estas plantas nadie va a echarles pesticida ni a tratar de controlar los insectos. Esto es lo más terrible, porque de padres enfermos salen hijos enfermos. En el campo teníamos unas plantas que antes eran verdes y de hojas grandes y bonitas y con unas florecitas amarillas; ahora estas plantas son de hoja pequeña, toda clorótica y enferma.

El virus que afectó a Autlán viene del tabaco; se le conoce como virus del tabaco y ocupa vectores para ser transmitido. La zona del valle más afectada por la plaga fue la más seca, donde tengo la empacadora. Es tierra de muy baja calidad; es pura arena. Ahí los pulgones y las mosquitas blancas se encuentran en el pasto y cuando se seca la vegetación todos se vienen a los campos de jitomate. Las fumigadas les valen madres, porque te vienen por millones. En los terrenos donde hay más humedad hay menor incidencia, porque los insectos llegan más tarde y en menor cantidad.

En México hay el dicho de que "muerto el niño, tapan el pozo". Ahora los empleados de la Secretaría de Agricultura y Ganadería andan queriendo que, una vez terminada la cosecha, rápido se quiten las plantas para que no sirvan de hospederas del virus y se deje al menos seis meses sin tomate el valle. Se requieren, sin embargo, otras medidas para las cuales no tenemos la capacidad cultural ni política para llevarlas a cabo y mejorar las condicio- 


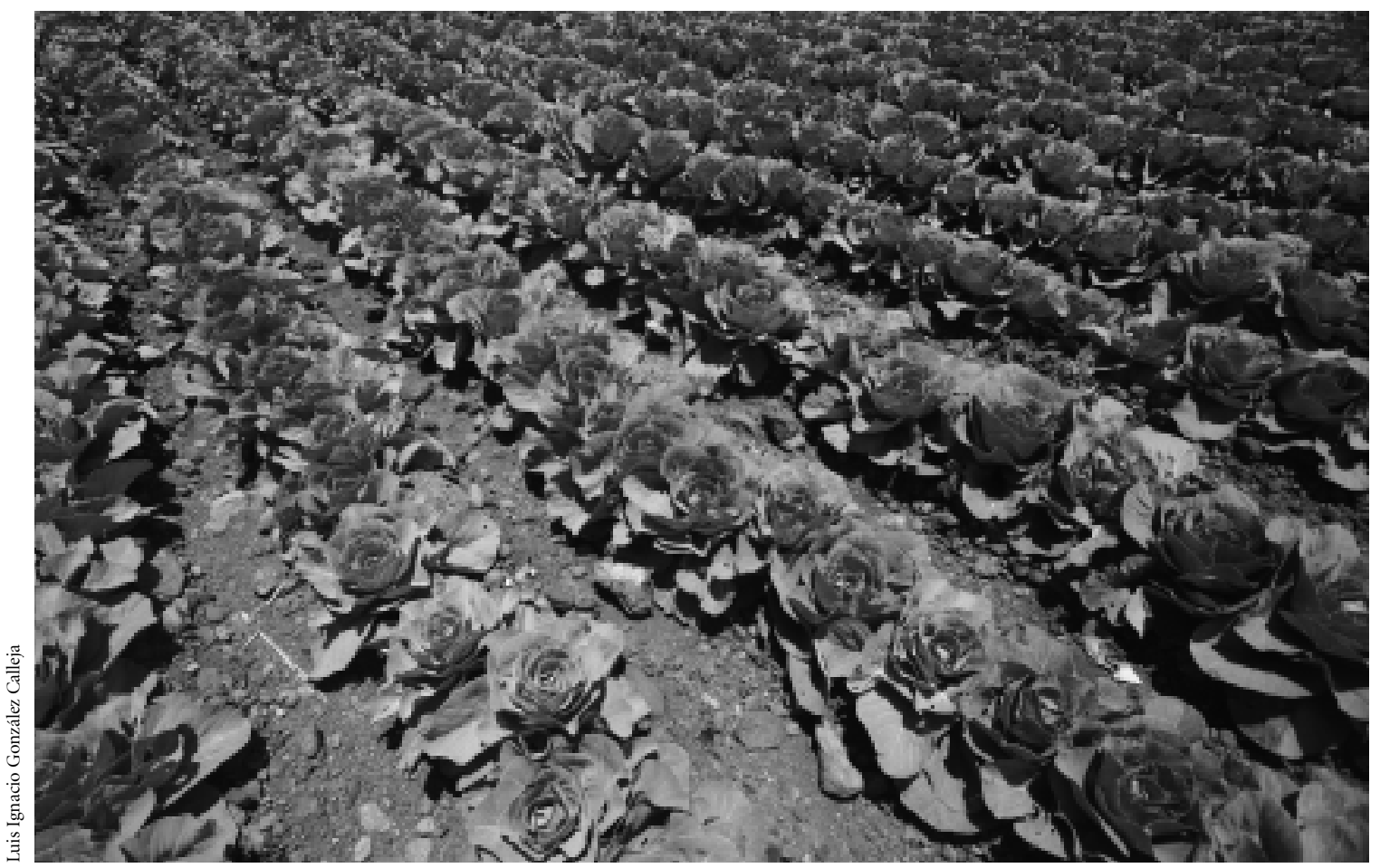

Zurcos de col. Atizapán El Alto, Jalisco.

nes ecológicas del valle. Un grupo de cinco o seis agricultores mandamos a Japón a un ingeniero químico y a un agrónomo con especialidad en fisiología vegetal y amplia experiencia en insecticidas y fungicidas para que buscaran algo que pudiera ayudarnos a salvar el valle. Algo que nunca debió haber sucedido. No teníamos que haber llegado a esta situación. Pero nuestra incultura y nuestra situación política no lo pudieron impedir.

Yo creo que todo lo que le sucede al mundo no es más que el enfoque hedonista que le damos a todo. Lo que sea, que sea en este momento, y lo demás, no importa. Ya llegó el hedonismo a la agricultura. El agricultor piensa que "lo que me vaya a dar, ahorita; lo demás, me importa un cacahuate". El hedonismo lo encontramos en los que aplican insecticidas. Aquí en Autlán se están utilizando productos altamente tóxicos que están prohibidos en México y en todo el mundo, porque es un crimen utilizarlos. Pero hoy están siendo empleados precisamente con hortalizas, que son para consumo humano; ade- más, se aplican sobre el personal que trabaja dentro del campo. Estamos hablando de DDT, y se utiliza ahorita porque se cree que es la única forma de poder producir. Si vamos a llegar a DDT, más vale no cultivar, porque no vamos a producir frutas sino veneno. Esto último, aparte de que es una tragedia ecológica, porque arrasa con todo lo viviente excepto con las plantas, a las cuales también se intoxica con dosis masivas. Yo creo que [de] producir con esas bases más vale no producir o buscar otro sistema u otra zona.

\section{La nueva conquista: el Llano de Rulfo}

[La siguiente narración de Roberto Vargas se realizó durante el recorrido en camioneta por un valle que abarca los municipios de Tonaya y Venustiano Carranza (antes San Gabriel) en el estado de Jalisco, localizados a hora y media de Autlán, el 12 de noviembre de 1987.] 
Mira, estás viendo nacer una idea precisamente en el Llano en llamas que describe Juan Rulfo. Revisa su libro de cuentos y vas a ver que se refiere a este valle. La población de Comala en la novela Pedro Páramo es en realidad Tuxcacuesco, pero no le llamó así [por] el nombre $\tan$ difícil que tiene. Revisa la descripción sobre el descenso al pueblo por la cuesta y la entrada al mismo y vas a darte cuenta [de] que se está refiriendo a Tuxcacuesco. No cabe la menor duda. Ahora bien, precisamente en el llano seco y miserable que describe Rulfo queremos hacer un emporio. Tenemos la tecnología, los recursos humanos y la necesidad de hacerlo. Tenemos todo para hacerlo.

En Autlán ya no vamos a poder trabajar. Ahí dábamos empleo a unas 350 gentes y ya las despedimos. Pero lo que no hicimos allá, podemos hacerlo aquí y darle ocupación a las gentes de aquí sin que tengan que irse lejos.

Nosotros queremos quedarnos cerca de Autlán [donde vive su familia]. Ya no queremos andar por toda la República. Mira, a raíz de que perdi[mos] en Autlán en el tomate en el año pasado, decidi[mos] sembrar sandía en Chiapas. Pens[amos] en este cultivo porque lo conocía[mos], porque no requiere mucha inversión y quería [mos] reponernos de las pérdidas que tuv[imos] en Autlán. La región de Chiapas la conocía[mos] porque ahí sembraban sandía y se daba bien. El resultado no fue lo que esperábamos, porque ganamos muy poquito, porque el precio estuvo bajo.

Como ves, es una zona de tierras muy pobres, pedregosas, con salitre, con muy baja precipitación pluvial. Algunos ejidos tienen miles de hectáreas, pero siembran el $10 \%$ de lo que tienen porque al fin y al cabo ni se va a dar nada, porque no llueve. No se siembran pastos porque ni se van a dar. No llueve. Habría pastos que resisten la sequía y son nutritivos para el ganado, pero lo que se ha hecho en esta zona por muchos años es un pastoreo muy rústico. Hay algunas partes de este valle con mayor capa de tierra agrícola y algunos ejidatarios con empuje y con mayores necesidades que hacen lo posible por sembrar. La precipitación pluvial de este valle es menor que la de Autlán, donde sabemos que es un área seca. Observa y te podrás dar cuenta [de] que se trata de una zona bastante pobre, bastante deprimida.
[Desde la camioneta Diego, que nos acompaña, interpela a un viejo que marchaba atrás de un burro cargado con leña:]

- ¿Cuánta tierra cultivan aquí?

-Más de la mitad. Pues como usted ya sabe, un año se siembra en un lado y otro año en otro.

-Ah, ¿y qué tanto llueve por aquí?

-Es malo. Ahí se da la cosecha ahí de vez en cuando.

$-¿$ Y hay heladas?

-Casi no, nomás sequedad. Los últimos años fueron regulares, pero antes de éstos fueron siete años en los que [se] sacaban tres cargas de maíz por hectárea [poco menos de un cuarto de tonelada].

-¿Qué hacen cuando no se les da la cosecha, de qué viven?

-Trabajando. Ya ve, en donde quiera hay jale. Otros años íbamos a Autlán, pero este año no han venido pa’ acá.

-¿Qué cultivos son los que siembran?

-Milo, maíz de comer, frijol, garbanzo y calabaza. Pero cuando no llueve mucho entonces toda se jode. A veces el frijol para cosecharlo nos llueve y también se nos jode.

-Hasta luego, que tenga buenas tardes.

Mira, el concepto de agricultura que tengo ahora es diferente al que tenía hace unos años. Tengo más información de lugares de México que anteriormente ni yo ni los que se encuentran ahora en Autlán teníamos. Yo pensaba que las tierras profundas, las tierras muy ricas, las zonas semitropicales y tropicales eran las buenas. Ahora mi información ha cambiado y sé que lo más importante es el clima y que donde haya menos humedad es mejor para la mayor parte de [los] cultivos. Donde hay menos precipitación pluvial hay muchas ventajas.

Mi perspectiva cambió cuando fui a conocer la horticultura en las Islas Canarias. Leí que en ese lugar estaban haciendo cosas maravillosas en la agricultura y que estaban exportando muchas hortalizas. Se decía que estas islas eran desérticas y me pregunté cómo es posible que de esas pequeñas islas estén mandando productos a Europa, Canadá y Estados Unidos. Me fui a conocerlas y al llegar renté un auto y pregunté a funcionarios de agricultura sobre quién era el más fuerte de ahí y me fui a verlo. Al 
rato ya éramos amigos, y hemos seguido siéndolo hasta ahora, porque lo he frecuentado y él me ha visitado.

Esto que ves aquí, en este llano, sería una riqueza extrema en las Islas Canarias. Aquel que tuviera este suelo, que es la parte más deprimida de este valle, sería una cosa fantástica. En las Islas Canarias, por ejemplo, no pueden meter arados y para hacer un hoyo y poner una planta casi requieres usar dinamita. Para hacer un hoyo - una fosa como dicen allá- tienen que utilizar una barra y golpear con ella hasta hacerlo; ahí se perfora hasta 300 metros de basalto - más duro que el tepetate de estas tierras- para sacar cinco, ocho o nueve litros por segundos de agua, la cual tiene por lo menos un gramo por litro de cloruro de sodio y es necesario filtrarla para quitárselo y cultivar sin dañar la tierra. Cuando ves que el suelo de ese lugar es diez veces peor que este [que] vemos en el Llano y el clima peor que el de aquí, te quedas maravillado de saber que producen jitomates de los cuales nosotros nunca hemos podido producir; con esa calidad extrema, para un mercado refinado, con alto poder adquisitivo. Ellos exportan y producen enormes cantidades de divisas.

Aquí en este valle la gente, si tuviera otra mentalidad, haría maravillas y se haría bastante rica. Los habitantes de estas tierras son muy pobres; pero la pobreza es una escala cultural. La pobreza es un estado de ánimo. Por ello, si cambias tu estado de ánimo y tu cultura, no hay pobreza. Un país es pobre en función de su estado de ánimo y de su cultura. Aquí no se hace nada porque no hay entusiasmo para producir y porque no se sabe producir.

¿Qué te parece esta zona? ¿Crees que Israel era mejor que esto que vemos aquí? Pero los israelitas están inundando el mercado de naranjos, de olivos y de hortalizas a Europa.

En la agricultura moderna no tiene que ver casi la tierra. Ésta no es importante en la agricultura de alta productividad. La tierra no tiene mayor importancia. El clima es lo importante, porque no lo puedes modificar, y si tratas de hacerlo con invernaderos, pues jte sale carísimo! Si tienes clima y agua aunque sea en pequeñas cantidades, todo lo demás se puede modificar. Aquí la tierra puede ser pobre en relación con la de Autlán, pero el clima es ideal. Esto vale una fortuna, esto es fantástico.
La agricultura ya cambió y en este valle árido y erosionado queremos hacer una cosa hermosa. Pienso yo que vamos a tener muchos menos insectos porque está seco, seco. Ya ves cómo se puede ver esta región tan árida y seca con otros ojos. Pues mira, viéndolo así, ¡hasta te entusiasmas, porque es que es hermoso hacer algo! ¿Sabes cuál es la gran expectativa que tengo aquí?: que de este mugrero se puede hacer una cosa preciosa. Yo gozo abriendo un potrero.

[Nos paramos junto a un joven y una señora que estaban alrededor de un hidrante con botes de plástico para llenarlos de agua. Diego se baja de la camioneta y le pregunta al joven:]

$-i$ Tienen agua todo el año?

-No. Hay veces que dura hasta cinco y seis semanas sin que el agua llegue hasta aquí, porque se escasea.

$-¿ Y$ qué hacen cuando no hay agua?

-Tenemos que ir hasta el manantial, pero queda lejos. Hay que caminar dos horas para poder llegar.

- ¿Hasta dónde llega la cola cuando hay mucha gente?

-Mmm, hasta el camino, y da vuelta [de ocho a diez metros].

[En ese momento llega una mujer que había dejado a uno de sus hijos en la cola y se dispuso a cargar las dos cubetas de diez litros para transportarlas. Sin embargo, hacía muy lentamente cada movimiento y escuchaba con atención, tratando de averiguar el porqué de nuestra presencia en el hidrante.]

- ¿Cómo verían ustedes si se hiciera un pozo y se le diera agua a la gente del pueblo? [dijo el señor Vargas.]

-¡Sería muy bueno! [dijo la mujer]. Fijese usted que cuando se escasea aquí en las llaves, los niños tienen que ir por ella en las mañanas y faltan a la escuela. Además, los hombres se levantan temprano para ir al manantial y poderse llevar agua al campo para tomar; ya ve que con este calor se necesita tomar mucha agua, y más cuando se está trabajando.

-Bueno, por aquí nos estaremos viendo. Hasta luego.

[Retomamos el recorrido en su camioneta rumbo al "rancho" de alrededor de cien hectáreas de don Simón, un 


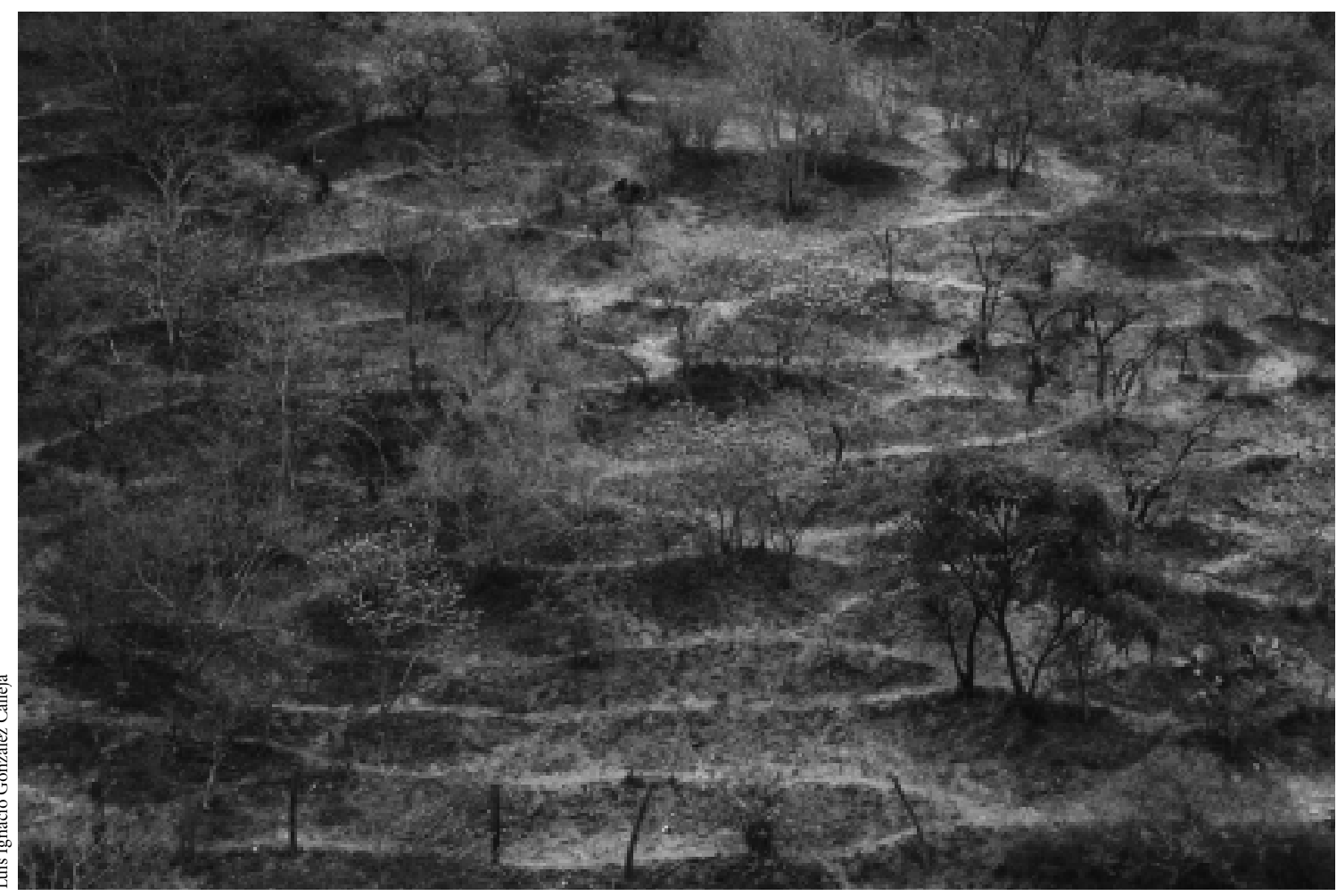

Pérdida de suelo e infertilidad. Autlán, Jalisco.

agricultor del Llano con quien había formado una sociedad. En aquel terreno habian perforado un pozo con una profundad de 250 metros y habian encontrado gran cantidad de agua. Retomamos de nuevo la conversación.]

En esta zona hay ejido y propiedad privada. Queremos dar empleo a unas 500 personas, las cuales no tienen nada que hacer. Estamos en una zona de lluvias erráticas, donde sólo progresan los huisaches. Se pueden invertir unos cuatro millones de pesos por hectárea, o sea que se pueden invertir en estas cien hectáreas que queremos sembrar mayores recursos de los que se podrían invertir en las cuatro mil hectáreas que forman dos ejidos. Se piensa dar más ocupación que lo que se da en las cuatro mil hectáreas.

Para irrigar las cien hectáreas de terreno pienso completar cuatro pozos profundos de 200 metros, colocar las bombas a 170 metros y sacar en total 30 litros por segundo.
La idea es meterme sólo con mi gente. Porque hay gente [de los horticultores de Autlán y de otras regiones] que tiene las antenas puestas y sabe que he estado viniendo por acá. A mí se me vacila mucho, pero se hace lo que hago [se refiere al riego por goteo y a la introducción de nuevas variedades de semillas en Autlán]. Ellos se dedican a hacer el dinero y yo gasto en investigación y arriesgo. En este valle, la cosa es estar solos, porque si no, después va a ser pura plaga. Para acá hay una barranca y para el lado contrario no se nos puede meter mucha gente porque está el cerro.

Yo, sin embargo, hago partícipe a gente joven para que invierta aquí. Te invito a ti, si quieres entrarle. Aquí puedes comprar un terrenito, escriturarlo para que sea tuyo y le metan huevo. Yo tengo 44 años y necesito aprovechar mi experiencia en un proyecto como esta zona, que puede ser muy buena. Tú verás que ahorita la hectárea se va a comprar a 200 mil pesos, se le va a invertir un 
promedio más o menos de 300 mil y, cuando tengas gastados 500 mil, tu hectárea va a valer dos millones de pesos. Con los beneficios de la primera cosecha -si es buena cosecha- se paga todo. Y aunque sea mala, de todos modos esto llega a ser negocio.

Mira, frente a esta situación que vemos en el valle lo único que le da a uno es vergüenza, dolor y angustia por la política que tenemos en México. El gobierno premia al güevón dándole intereses altos para que meta su dinero al banco y gane sin trabajar; en cambio, se limita al que invierte cobrándole muy caro el dinero que necesita para invertir en el campo. Nuestro país es un país de Kafka, y no digo de caca porque es mi país y lo adoro.

El problema de la alimentación de México básicamente es que existe una enorme presión en contra del que tenga una propiedad agrícola bien explotada. Mira, en la medida en que sea mal explotada no hay problema; pero en la medida [en] que se vuelva algo interesante, algo que llame la atención, hay problemas. Mira, si hay terrenos mal nivelados es porque el sistema político mexicano no permite que se nivelen los terrenos. Aquí todo está limitado por la cosa política. En México la producción agropecuaria está limitadísima. Si tienes una propiedad y una producción en malas condiciones, tendrás menos problemas políticos y sociales. Pero si eres buen agricultor, tendrás más problemas. No se puede trabajar. Es muy difícil conservar la propiedad privada en el campo. Tienes que sostener[la] a base de amistades, a base de dinero y a base de políticas, y a base de fuerza y de armas y, al final, con un poquito de leyes. Esto último es lo menos importante.

Este terreno es una cosa maravillosa, pero el problema es que me dejen producir. Para producir hortalizas necesitamos que haya mucho orden por aquí. ¡Que haya orden! [remarcó en tono más alto]. Te has preguntado qué tiene más valor social, ¿una empresa como la que queremos hacer o diez o veinte ejidos como los que hay en estas tierras? Para un político tienen más valor los ejidos porque le dan fuerza y, sobre todo, votos.

[Incrédulo sobre sus temores, le pregunté qué tipo de problemas pensaba que lo podían afectar. Me contestó en tono exasperado:] Tú crees que no es posible que algún cabrón, que puede ser un político, el cacique de algún pue- blo o el acaparador y que tengan coraje de que la gente tenga dinero y que ya no les haga caso como antes o no los deje trabajar como antes. Si alguno de ellos se ve afectado puede mandar a alguien para que le dé a uno en la madre, $\mathrm{o}$ al negocio; puede decirle a alguien: "Mételo en una bronca sindical, hazle un problema agrario en su propiedad, busca gente para que se metan al terreno hasta que ese cabrón se vaya de aquí." También puede decir: "Yo he sido diputado tantos años de la zona y nunca he podido hacer nada, y mira lo que este cabrón está haciendo. Sabrá Dios qué vaya a querer. Mejor ándale y chíngatelo." Te preguntarás para qué puede hacer esto, y te respondo: para que sigan las cosas igual. También aquí hay curas comunistas y maestros que levantan a la gente y que tienen miedo de que la gente ya no les vaya a hacer caso.

[Después de un malogrado intento de sociedad con un agricultor del área, Roberto Vargas logró formar, cuatro años después de esta visita, la empresa Oasis del Desierto, con una extensión de 1200 hectáreas de terreno, en las que perforó dos pozos que le permitieron irrigar 450 hectáreas con el sistema de riego por goteo. Esta empresa se dedicó principalmente a producir hortalizas para el mercado de Estados Unidos. En esta sociedad participaron como socios minoritarios algunos de sus hermanos y otros pequeños inversionistas amigos de él. A esta región llegaron posteriormente empresas estadounidenses y mexicanas con tecnologías importadas que se abocaron a los mismos cultivos y al mismo mercado. Hoy día, a esta región vienen en camiones de las compañias trabajadores del valle de Autlán-El Grullo, ya que la mano de obra local es insuficiente.]

\section{UN PERFIL COMÚN DE TRES PERSONAJES}

En los tres relatos, en los personajes detonadores del cambio agrícola predomina la concepción de que el desarrollo agropecuario se reduce a incrementar vertiginosamente la productividad, la rentabilidad, la competitividad y el empleo; comparten la certidumbre de que la "nueva" tecnología y el proyecto que ellos pretenden desarrollar son el motor del cambio regional y nacional; por ello, son claros en enfatizar que debe dejárseles actuar sin corta- 
pisas políticas. Comparten una fe ciega en que la naturaleza es pródiga y sólo aceptan los efectos perversos de su actividad productiva una vez que se rebasó de manera irreparable el límite de recuperación del ecosistema que los albergó. Desde su perspectiva, los grandes retos son abrir tierras a la producción agrícola y ganadera comercial, introducir nuevas variedades de semillas y razas en la ganadería, encontrar y “aprovechar" los mantos acuíferos o utilizar las inversiones públicas en sistemas de irrigación. En un principio no reparan en los desequilibrios y en los trastornos ambientales, pero los reconocen cuando se convierten en una amenazan o en un límite a su proyecto empresarial.

Comparten, también, el arrojo y la determinación para desarrollar un proyecto empresarial que los lugareños no alcanzan a imaginar, ni pueden anticipar las consecuencias de los cambios que, con su anuencia y sin ella, realizan los "fuereños". Éstos concentran no sólo recursos económicos y tecnológicos nunca antes utilizados localmente, sino también cuentan con una gran capacidad para afrontar riesgos, innovar y adaptarse a las circunstancias cambiantes de la región donde operan; conocen, además, las oportunidades del mercado nacional y/o internacional y cuentan con relaciones para contactar a los distribuidores y mayoristas; por último, es sobresaliente su habilidad para negociar y canalizar recursos públicos a las regiones donde operan. La producción y la política en estas regiones de frontera están estrechamente entrelazadas a partir de relaciones personales. El funcionario estatal y federal y el cacique regional se alían en la gestión de los recursos públicos que requiere el desarrollo agrícola empresarial orientado al mercado nacional e internacional; también cabe la posibilidad, como lo advierte el último relato, de que el cacique local se vea amenazado y saboteé localmente el proyecto agrícola que trastoca económica y políticamente la región.

\section{Bibliografía}

Fábregas, A., 1994, El concepto de frontera en la frontera sur, Gobierno del Estado de Chiapas, Consejo Estatal de Fomento a la Investigación y Difusión de la Cultura, DIF-
Chiapas, Instituto Chiapaneco de Cultura, Tuxtla Gutiérrez.

Garzón, A., 2002, "El papel de la paratioza cockerelli en la transmisión de fitoplasmas en tomate. Culiacán, Sinaloa", Instituto Nacional de Investigaciones Forestales, Agrícolas y Pecuarias, Fundación Produce del Estado de Sinaloa, en <http://www.fps.org.mx/cgi/articles.cgi? Action $=$ View\&Article $=10>$, consultado el 25 de junio de 2006

González, H., 1993, "Liberalización económica y agricultura de exportación en la región Costa de Jalisco", en J. Arroyo y D. Loren (eds.), Impactos regionales de la apertura comercial, Universidad de Guadalajara, Universidad de California, Guadalajara.

__, 1994, "El uso del agua del subsuelo: sostenibilidad e internacionalización. Un estudio de caso en la Costa de Jalisco, México", en C. Viqueira y L. Torre (eds.), Sistemas hidráulicos, modernización de la agricultura y migración, El Colegio Mexiquense, Universidad Iberoamericana, México.

_ _ 2004, "La sustentabilidad y las cadenas globales de mercancías: la agricultura de exportación en México", en M. del Valle (ed.), El desarrollo agrícola y rural del Tercer Mundo en el contexto de la mundialización, Universidad Nacional Autónoma de México, Plaza y Valdés, México.

_ y M. Calleja, 1998, "La construcción de cadenas internacionales de frutas y hortalizas: vínculos e interdependencia entre Texas y México", en H. Grammont, $\mathrm{H}$. González, M. Gómez y R. Schwentesius (eds.), Agricultura de exportación en tiempos de globalización: el caso de las hortalizas, frutas y flores, Juan Pablo Editores, Centro de Investigaciones y Estudios Superiores en Antropología Social, Universidad Nacional Autónoma de México, Universidad Autónoma de Chihuahua, México.

Macías, A., 2006, Empresarios, estrategias y territorio en la producción hortícola en México (El caso de Sayula, Jalisco), Centro de Investigaciones y Estudios Superiores en Antropología Social, Guadalajara.

Pérez-Prado, L., 2002, Flowing Waters, Dripping Waters. State Intervention, Local Politics and Water Management in Midwestern Mexico, Universidad de Manchester, Manchester.

Román, T. y P. Silva, 2006, "Combinando esfuerzos y voluntades en la cuenca del río Ayuquila-Armería", en $<\mathrm{http}$ : //www.bvsde.paho.org/bvsacg/e/foro4/18MARZO/wat er/Combinando.pdf $>$, consultado el 15 de julio de 2007.

Schumpeter, J., 1997, Teoría del desenvolvmiento económico, Fondo de Cultura Económica, México.

Turner, F. J., 1962, The Frontier in American History, Holt, Nueva York. 